\title{
Zooplankton abundance, species composition and ecology of tropical high-mountain crater Lake Wonchi, Ethiopia
}

\author{
Fasil DEGEFU,, $2^{1 *}$ Michael SCHAGERL ${ }^{2}$ \\ ${ }^{1}$ National Fisheries and Other Living Aquatic Resources Research Center, P.O. Box 64, Sebeta, Ethiopia; ${ }^{2}$ Department of Limnology \\ and Oceanography, University of Vienna, Althanstrasse 14, 1090 Vienna, Austria \\ *Corresponding author: fdegefu7@gmail.com
}

\begin{abstract}
The highlands of Ethiopia represent some of the remnants of undisturbed aquatic ecosystems; they are however highly threatened by significant socio-economic developments and associated anthropogenic impacts. Lake Wonchi is one of the few remaining fairly pristine high-mountain crater lakes in the central highlands and has never been investigated in detail. We present a first study on zooplankton taxa composition, abundance and biomass conducted over more than one year including the underlying environmental drivers. The lake is basic (pH 7.9-8.9), dilute (specific conductivity 185-245 $\mu \mathrm{S} \mathrm{cm}^{-1}$ ) and oligotrophic with mean trophic status index of 36. The zooplankton community composition showed low species richness comprising a total of fourteen taxa with six cladocerans, one copepod and seven rotifers. Simpson's index of diversity with values between 0.6 and 0.8 pointed towards a homogenous taxa occurrence

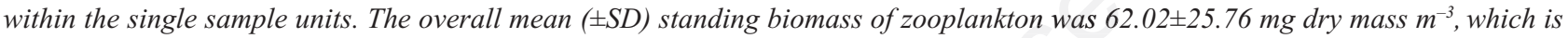
low compared to other highland and rift valley lakes in Ethiopia. Cyclopoid copepods, in particular Thermocyclops ethiopiensis were the most abundant group and contributed 50\% to the total zooplankton abundance followed by cladocerans (38\%) and rotifers (12\%). Non-metric multi-dimensional scaling resulted in a 3-dimensional model, which revealed similar community composition on successive sampling dates except in December/January and May. Temperature, alkalinity, conductivity and nitrate-N had significant influence on this seasonal pattern. A weak, but significant positive correlation ( $r=0.482, N=20, P=0.037)$ between Chlorophyll a and zooplankton biomass mirrors a bottom-up effect of phytoplankton biomass on zooplankton dynamics. The zooplankton of Lake Wonchi displayed some degree of segregation along the epi-and metalimnion during this study, but diel vertical migration was not observed. The results show that fish predation is not the key factor in structuring the vertical distribution of zooplankton in Lake Wonchi.
\end{abstract}

Key words: Lake Wonchi, zooplankton, competition, vertical distribution, trophic classification.

Received: July 2014. Accepted: November 2014.

\section{INTRODUCTION}

Although zooplankton research of Ethiopian lakes started already in the 1930's (Bryce, 1931; Cannicci and Almagia, 1947), our contemporary knowledge is far from complete. Former studies were based mainly on samples collected by expeditions, and thus provided scanty information on long-term patterns in their seasonality and dynamics. Nevertheless, our understanding on zooplankton in East Africa has been slowly developing (Defaye, 1988; Fernando et al., 1990; Mengestou et al., 1991; Dagne et al., 2008). Some studies were able to explore zooplankton associations along ecosystem gradients mainly in the rift valley region and the Bishoftu crater lakes (Wodajo and Belay, 1984; Green and Mengestou, 1991; Mengestou and Fernando, 1991; Vijverberg et al., 2014). However, compared to rift valley and Bishoftu crater lakes, zooplankton from highland lakes in Ethiopia have been studied only sporadically, with only a few exceptions (Dejen et al., 2013; Fetahi et al., 2011; Dejenie et al., 2012). This is particularly true of the deep crater Lake Wonchi in the central highlands which has never been investigated in detail to the best of our knowledge, presumably due to seclusion and lack of infrastructure. Nevertheless, the lake is becoming a touristic destination with a corresponding increase in newly erected resorts and tourist facilities in the lake basin, which involve modifications of the crater rim and shoreline. Such aggressive land grabbing and encroachments do not only displace and evict riparian communities; they also stop the tradition of local people for keeping conservation and sustainable management of natural resources and jeopardize aquatic biodiversity. Common carp (Cyprinus carpio L. 1758) and tilapia (Oreochromis niloticus L.) fish were introduced in Lake Wonchi without any previous knowledge of the lake limnology by the National Fisheries and Other Aquatic Life Research Centre (NFLARC) in the late 1990s in an attempt to establish a pelagic fishery and to increase availability of protein for the local communities. Degefu et al. (2014) did a snap-shot survey on the ichthyofauna of the lake and reported that the latter species did not establish breeding populations. Probably low plankton biomass, which is the main food source for planktivorous fish like 
O. niloticus (Tudorancea et al., 1988) and low water temperature, could be causes behind the failure of $O$. niloticus to inhabit this water body.

The productivity of aquatic ecosystems is strongly influenced by the amount of available resources (bottomup control), however, it is often the food web structure, particularly the abundance and size structure of the zoo-

Tab. 1. Morphometry of Lake Wonchi.

\begin{tabular}{lc} 
Variables & Values \\
Location & $8^{\circ} 47^{\prime} \mathrm{N} 7^{\circ} 53^{\prime} \mathrm{E}$ \\
Max. length (east-west: $60^{\circ}$ from north) & $3.8 \mathrm{~km}$ \\
\hline Max. width & $2.2 \mathrm{~km}$ \\
Max. depth & $107 \mathrm{~m}$ \\
\hline Mean depth & $28 \mathrm{~m}$ \\
Shoreline length & $13.362 \mathrm{~km}$ \\
\hline Surface area & $5.6 \mathrm{~km}^{2}$ \\
Volume & $0.185 \mathrm{~km}^{3}$ \\
\hline
\end{tabular}

plankton (top-down grazing effect), which suppress phytoplankton biomass (Lampert and Sommer, 1997). Therefore, comprehensive understanding of zooplankton dynamics in aquatic ecosystems has an implication for fish recruitment and production (Brooks and Dodson, 1965; Carpenter and Kitchell, 1993). We studied for the first time the seasonal dynamics of zooplankton in relation to underlying environmental variables over 14 months in a deep tropical-highland crater Lake. Further, it was also an objective to corroborate if zooplankton undergoes diel vertical migration in the lake where strict-planktivorous fish is absent.

\section{METHODS}

\section{Study area}

The deep oligotrophic crater lake Wonchi is located at $8^{\circ} 47^{\prime} \mathrm{N}$ and $37^{\circ} 53^{\prime} \mathrm{E}$ at an altitude of $2887 \mathrm{~m}$ above sea level some $150 \mathrm{~km}$ southwest of the capital city of Ethiopia Addis Ababa. It is deep, steeply shelving with a surface area of $5.6 \mathrm{~km}^{2}$ (Tab. 1; Fig. 1). The shoreline is mostly rocky and gravelly and inhabited by beds of sub-

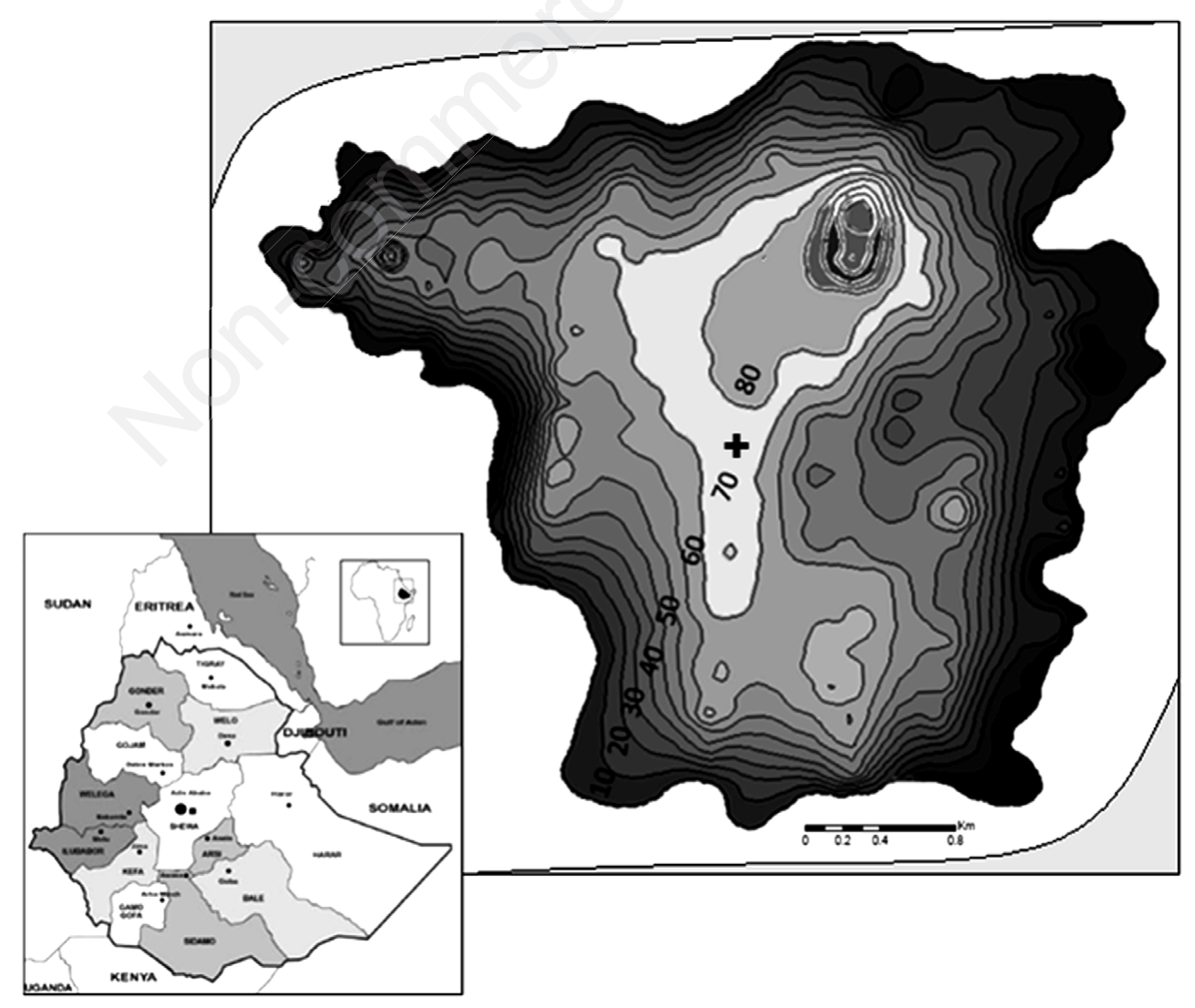

Fig. 1. Bathymetric map of Lake Wonchi in southwest escarpment of Ethiopia. \&, primary sampling site with GPS coordinates $08^{\circ} 48^{\prime} 035^{\prime \prime} \mathrm{N}$ and $37^{\circ} 53^{\prime} 592^{\prime \prime} \mathrm{E}$. 
merged aquatic macrophytes of mainly Potomageton sp. The height of its crater rim from the lake surface is about $460 \mathrm{~m}$. The Lake has a closed basin with no surface inlet. It receives water primarily from rainfall and subterranean cold and lukewarm springs. Meteorological data such as rainfall and air-temperature showed a clear seasonality in Lake Wonchi. There are two rainy seasons in the area: the main rainy season is between May and September peaking during July and August, while the minor one extending from February to March. The cold-dry season is distinguished between October and January. Generally, the lake region is characterized by sub-humid climate with an annual rainfall of $1200 \mathrm{~mm}$. The diel air temperature varies from 13 to $22^{\circ} \mathrm{C}$ during the day time and falls below $10^{\circ} \mathrm{C}$ in the night (Ethiopia National Meteorological Service Agency).

\section{Field sampling and analyses}

The study was carried out on a fortnightly basis between December 2011 and January 2013 at an open-water station marked with GPS (depth: $50 \mathrm{~m}$, coordinates: $08^{\circ} 48^{\prime} 035^{\prime \prime} \mathrm{N}$ and $\left.37^{\circ} 53^{\prime} 592^{\prime \prime} \mathrm{E}\right)$. Physico-chemical variables such as water temperature, dissolved oxygen (DO), specific conductivity (corrected to $25^{\circ} \mathrm{C}$ ) and $\mathrm{pH}$ were measured in situ in vertical profiles using a multi-probe (Model HQ40D, HACH Instruments). Water for chlorophyll- $a$ (Chl- $a$ ), element and nutrient analysis was collected from depth profiles (surface, 1, 2, 3, 4, 5, 7, 10, 15, $20,30,40,50 \mathrm{~m}$ depth) using $5 \mathrm{~L}$ Schindler sampler. Samples were transferred to $2 \mathrm{~L}$ acid-prewashed plastic bottles and stored in the dark in a cooling box $\left(4^{\circ} \mathrm{C}\right)$ until analyses of nutrients and alkalinity were made at National Fisheries and Aquaculture Research Center, Ethiopia. The samples were subsequently filtered within $4 \mathrm{~h}$ of sampling through glass fibre filters (Whatman GF/C) paper and the filtrate was used for nutrient analyses, which were done within $48 \mathrm{~h}$ of sample collection. Ammonium $\left(\mathrm{NH}_{4}-\mathrm{N}\right)$ was analysed by the Indol-phenol blue method after APHA (1998), nitrate $\left(\mathrm{NO}_{3}-\mathrm{N}\right)$ was determined with sodium-salicylate method as outlined by APHA (1998) and nitrite $\left(\mathrm{NO}_{2}-\mathrm{N}\right)$ was analysed based on the reaction between sulphanilamide and N-naphthyl-(1)-ethylendiamin-dihydrochloride (APHA, 1998). Soluble reactive phosphorus (SRP) was determined by ascorbic acid method (APHA, 1998), while total phosphorus $\left(\mathrm{P}_{\text {tot }}\right)$ was determined by digesting the unfiltered water samples in an autoclave for $50 \mathrm{~min}$ using potassium-peroxodisulphate to convert the organically bounded phosphorus into orthophosphate. Total alkalinity was determined from the unfiltered water sample through titration with $0.01 \mathrm{~N} \mathrm{HCl}$ to $\mathrm{pH} 4.3$ (Wetzel and Likens, 2000). Chl $-a$ concentration was analysed spectrophotometrically after extracting GF/C glass-fibre filtered samples with $90 \%$ acetone without phaeopigments correction (Talling and Driver, 1963).
Subsequently, the Trophic State Index (TSI) proposed by Carlson (1977) was computed based on transparency, Chl$a$, total dissolved nitrogen (TDN) and $\mathrm{P}_{\text {tot }}$. For qualitative zooplankton analysis, triplicate samples were collected from two stations (littoral and pelagic zone) using plankton nets of 30 and $100 \mu \mathrm{m}$ mesh size for rotifers and crustaceans, respectively. Zooplankton was enumerated and identified down to species level under a WILD stereoscope microscope (magnification 100-400x) using keys of Koste (1978), Defaye (1988), Korovchinsky (1992), Korinek (1999) and Fernando (2002). To determine numerical abundance, samples were collected from depth profiles using a $5 \mathrm{~L}$ Schindler sampler (surface, 1, 2, 3, 5, $7,10,15$ and $20 \mathrm{~m}$ ). Water samples were filtered and concentrated through plankton gauze of $30 \mu \mathrm{m}$ mesh size to ensure inclusion of rotifers and preserved with sugar-formalin solution to a final concentration of $4 \%$. Total counts were made from the concentrated original whole-samples (samples were poured into a gridded glass chamber where each grid was counted and hand-tallied) and individual densities expressed as number per $\mathrm{m}^{3}$. All developmental stages of copepod species were pooled together and counted as total copepodites and nauplii stages, while for cladocerans all stages were counted together as one age class. For biomass estimation, the entire samples during the study periods were pooled, 50-100 (based on their densities) individuals with different size class were randomly sorted and body lengths measured. The body size of crustaceans was measured excluding the caudal setae, spines and projections and converted into biomass according to Dumont et al. (1975) via length-weight regression equations (intercept and slope for the regression equation were used from literature values for the respective species from similar size range ), using the formula:

$$
\ln (\mathrm{W})=\ln (\mathrm{a})+\mathrm{b} \ln (\mathrm{L})
$$

where

$\mathrm{L}=$ body length in $\mathrm{mm}$;

$\mathrm{a}=$ estimate of intercept;

$\mathrm{b}=$ estimate of the slope;

$\mathrm{W}=$ body mass in $\mu \mathrm{g}$ dry mass (DM).

Biovolumes of rotifers were computed from individual size measurements using geometric approximations as described by Ruttner-Kolisko (1977). These volumes were subsequently used to estimate fresh mass, assuming a density of 1.0 (volume of $10^{6} \mu \mathrm{m}^{3}=1 \mu \mathrm{g}$ fresh weight). A wet-dry mass conversion factor of 0.1 was used for all genera except for Asplanchna, for which a factor of 0.039 was considered (Dumont et al., 1975). Zooplankton species standing biomass was computed based on the product of species specific dry mass and mean abundance of species for the sampling date. A $24 \mathrm{~h}$ sampling program was carried out to consider zooplankton diel vertical mi- 
gration (DVM) in June 21-22, 2012 (weather condition: rainy; new moon). Samples were collected at $4 \mathrm{~h}$ intervals, between 6:00 a.m. in the first day and 2:00 a.m. the following day from surface, 1, 2, 3, 5, 7, 10, 15 and $20 \mathrm{~m}$ using a $5 \mathrm{~L}$ Schindler sampler. Subsequently, the samples were filtered, preserved and counted as described earlier.

\section{Data analysis}

To identify the dominance of single species/even taxa distribution, Simpson's index of diversity was estimated following McCune and Grace (2002). Similarity of species composition between consecutive sampling dates (pre-treatment of abundances $4^{\text {th }}$ root transformation for down weighting dominant taxa; Clarke and Gorley 2006) was assessed by Bray-Curtis similarity index. Non-metric multi-dimensional scaling (nMDS) was performed based on Bray-Curtis similarities in order to display succession patterns in the species composition during the sampling period. Subsequently, the community pattern along artificial axes obtained by nMDS were post-hoc related to environmental variables, normalized prior to calculations, by BIO-ENV ( 999 permutations, $\mathrm{P}=0.001$; $\mathrm{Rho}=0.359$ ). LINKTREE was employed to seek for variables and their values, which are responsible for dichotomous group separation (minimum group size, 1; minimum split size, 2; minimum split, $\mathrm{r}=0.0 ; \mathrm{P}=0.1$ ). The LINKTREE routine is a type of a non-parametric multivariate regression tree and combines environmental variables with biotic patterns to search for species-environment relationships (sometimes also called divisive clustering). It performs successive binary divisions of biotic patterns and tries to explain their similarities by most meaningful environmental variables. The LINKTREE procedure was combined with SIMPROF routine to test for significant explanations of the environmental variables (Clarke et al., 2008). All the statistical analyses were performed using the statistical package Primer 6 version 6.1.15 (Clarke and Gorley, 2006). One-way analysis of variance (ANOVA) was used to test the differences between all the environmental variables during the sampling period followed by the TukeyKramer post hoc multiple comparisons test; vertical measurements were treated as replicates. SPSS 16.0 software was used in the statistical analysis and variables were considered to be significant at $\mathrm{P}<0.05$. Graphs were constructed using Sigmaplot ver. 12.

\section{RESULTS}

\section{Climatic and physico-chemical variables}

Lake Wonchi is characterized by high underwater transparency (annual mean Secchi-depth $4 \mathrm{~m}$ ) and low water temperatures with a maximum of $17.5^{\circ} \mathrm{C}$ in April and a minimum of $14.8^{\circ} \mathrm{C}$ in January (Fig. 2). The vertical and seasonal variation of water temperature during the study period was small $\left(\leq 3^{\circ} \mathrm{C}\right.$, Fig. 2). There was a significant variation (ANOVA, $\mathrm{F}(20,254)=11.412, \mathrm{P}=0.00)$ in DO concentration over time, with the highest mean value of $8.0 \mathrm{mg} \mathrm{L}^{-1}(116 \%)$ recorded in June and the lowest mean value $3.4 \mathrm{mg} \mathrm{L}^{-1}$ (46\%) in February 2012 (Fig. 2 ). The lake water was generally basic and dilute with a relatively narrow range of $\mathrm{pH} 7.9$ to 8.9 and conductivity ranging from 186 to $245 \mu \mathrm{S} \mathrm{cm}^{-1}$, respectively. TDN and $\mathrm{P}_{\text {tot }}$ showed significant variation along the water column with annual mean $( \pm \mathrm{SD})$ values of $91 \pm 46$ and $6 \pm 3 \mu \mathrm{g}$ $\mathrm{L}^{-1}$, respectively, but the seasonal variation was not significant. Apparently, Chl- $a$ exhibited marked variations coupled with seasonality. The maximum value of $7.0 \mu \mathrm{g}$ $\mathrm{L}^{-1}$ was recorded in April during the dry period and decreased progressively to a minimum of $1.3 \mu \mathrm{g} \mathrm{L}^{-1}$ in September during the main rainy season (Fig. 3). Based on the TSI for Chl- $a, \mathrm{P}_{\text {tot, }}$ Secchi-depth and TDN values, the lake is categorized oligotrophic.

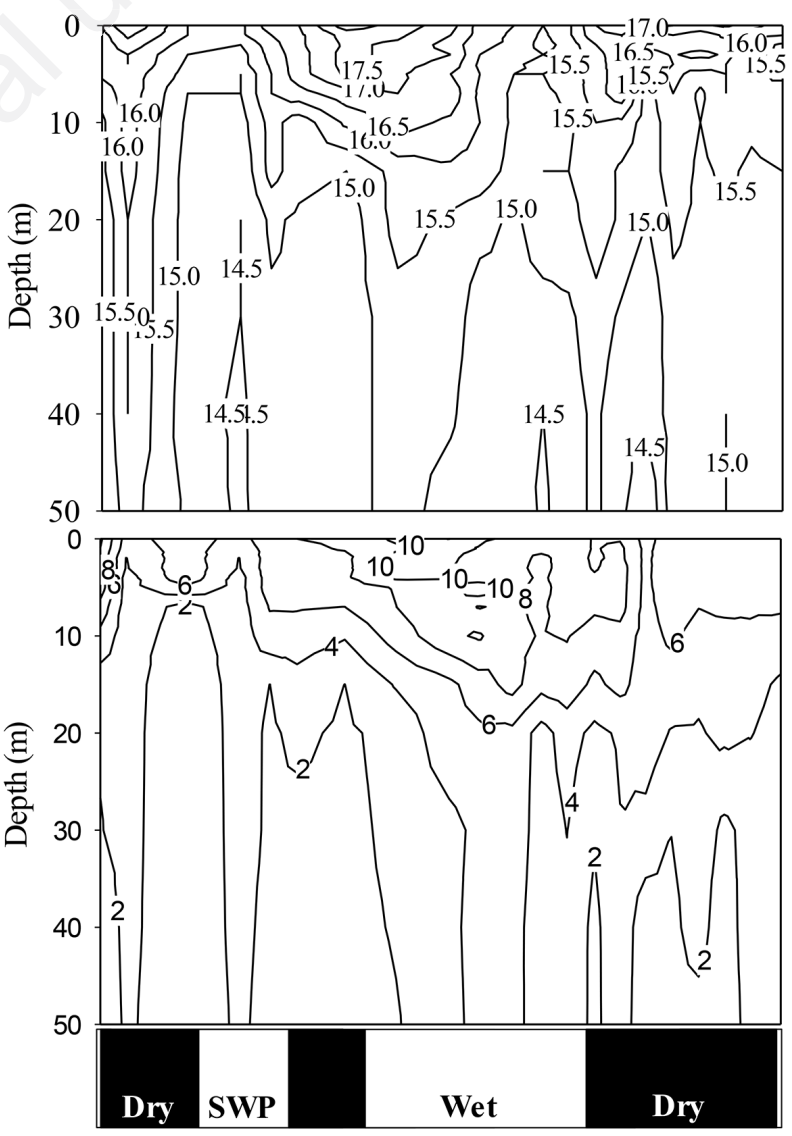

Fig. 2. Depth-time isopleths of temperature $\left({ }^{\circ} \mathrm{C}\right.$, top panel) and dissolved oxygen concentrations ( $\mathrm{mg} \mathrm{L}^{-1}$, bottom panel) in Lake Wonchi during the sampling period, from December 2011 to January 2013. Dry, dry season: October-January and April; SWP, short wet season: February-March; Wet, wet season: May-September. 


\section{Spatio-temporal patterns in the zooplankton community and biomass}

A total of fourteen zooplankton taxa were identified indicating low species richness: six cladocerans, one copepod and seven rotifers. Seven species comprised more than $95 \%$ of the total zooplankton abundance (Tab. 2) with copepods being the most abundant group ( $50 \%$ contribution to the total zooplankton abundance) followed by cladocerans $(38 \%)$ and rotifers (12\%, Tab. 2). Nevertheless, copepods were the least in terms of species richness and represented only by Thermocyclops ethiopiensis (Tab. 2). Simpson's index of diversity with values between 0.6 and 0.8 (Fig. 4, center panel) pointed towards a homogenous taxa occurrence within the single sample units; Bray-Curtis similarity showed comparable community patterns on consecutive sampling dates (Fig. 4, bottom panel). However, zooplankton abundance exhibited temporal variations in concomitance with wet and dry period, with copepods ranging from $3 \times 10^{3}$ to $118 \times 0^{3}$ and from $0.6 \times 10^{3}$ to $63 \times 10^{3} \mathrm{Ind}^{-3}$ during dry and peak rainy season, respectively. Amongst the cladocerans, Daphnia longispina, Ceriodaphnia reticulata and Bosmina longirostris (which accounted for 40\%, 22\% and $31 \%$ of total cladocerans, respectively) were dominant throughout the sampling period (Tab. 2). Other cladoceran species such as Diaphanosoma excisum and Moina micrura (which made up to $7 \%$ of the cladoceran community) were common, whereas Chydorus sphaericus was very rare (Tab. 2). Apparently, D. longispina, C. reticulata and Diaphanosoma excisum did not co-exist in higher number: $D$. longispina significantly dominated (40\%) the cladoceran community and the latter two species were either absent or present at very low abundance. The rotifers in Lake Wonchi are typical cosmopolitan species (Tab. 2). The annual mean abundance of rotifers $\left(8 \times 10^{3} \mathrm{Ind} \mathrm{m}^{-3}\right)$ was 5 -fold lower than crustaceans $\left(42 \times 10^{3} \mathrm{Ind} \mathrm{m}^{-3}\right)$. Keratella cochlearis and Asplanchna sieboldii were the dominant rotifer species and accounted more than $88 \%$ to the total rotifer abundance. $K$. cochlearis attained the highest mean abundance $\left(19 \times 10^{3}\right.$ Ind $\mathrm{m}^{-3}$ ) in June/July 2012 and almost disappeared during the short-wet period when the cladocerans abundance peaked $\left(41 \times 10^{3}\right.$ Ind $\left.\mathrm{m}^{-3}\right)$. Apparently, the omnivorous in-

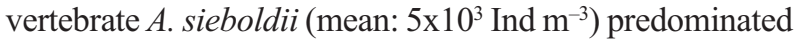

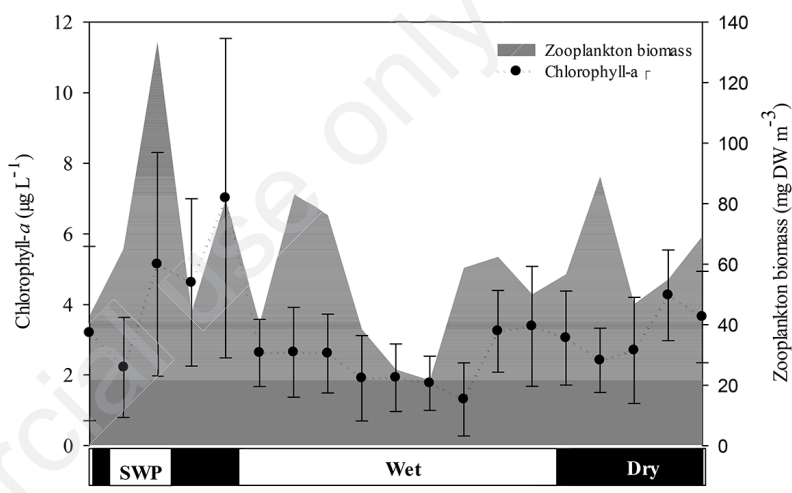

Fig. 3. Temporal trends in mean $( \pm \mathrm{SD})$ phytoplankton biomass (Chl- $a, \mu \mathrm{g} \mathrm{L}^{-1}$ ) and total zooplankton standing biomass (mg DW $\mathrm{m}^{-3}$ ) in Lake Wonchi during the study period. Dry, dry season: October-January and April; SWP, short wet season: FebruaryMarch; Wet, wet season: May-September.

Tab. 2. Zooplankton species found in Lake Wonchi with their mean relative abundance based on Ind $\mathrm{m}^{-3}$, average biomass and size during December 2011 to January 2013.

\begin{tabular}{|c|c|c|c|}
\hline Zooplankton groups & Relative abundance (\%) & Average biomass ( $\mu \mathrm{g})$ & Average length (mm) \\
\hline \multicolumn{4}{|l|}{ Copepoda } \\
\hline Thermocyclops ethiopiensis Kiefer, 1934 & 29.60 & 21.44 & 0.641 \\
\hline nauplii & 20.45 & 1.85 & 0.162 \\
\hline \multicolumn{4}{|l|}{ Cladocera } \\
\hline Daphnia longispina (O.F. Müller, 1776) & 14.33 & 21.10 & 1.112 \\
\hline Diaphanosoma excisum Sars, 1885 & 1.43 & 1.25 & 0.672 \\
\hline Bosmina longirostris (O.F. Müller, 1776) & 13.64 & 4.74 & 0.381 \\
\hline Ceriodaphnia reticulata Jurine & 7.04 & 4.96 & 0.573 \\
\hline Moina micrura Kurz, 1874 & 1.51 & 1.00 & 0.524 \\
\hline \multicolumn{4}{|l|}{ Chydorus sphaericus (Müller, 1785) } \\
\hline \multicolumn{4}{|l|}{ Rotifera } \\
\hline Asplanchna sieboldii (Leydig, 1854) & 2.23 & 5.89 & 0.867 \\
\hline Trichocerca gracilis (Tessin, 1890) & 0.26 & 0.006 & 0.197 \\
\hline \multicolumn{4}{|l|}{ Filinia longiseta } \\
\hline Keratella cochlearis (Gosse, 1855) & 9.06 & 0.005 & 0.128 \\
\hline Polyarthra sp. & & & \\
\hline Brachionus caudatus Barrois \& Daday, 1894, 1766 & 0.41 & 0.008 & 0.143 \\
\hline
\end{tabular}


the total rotifer community in November and April 2012 during the cold-dry months.

The pelagic zooplankton standing biomass in Lake Wonchi showed seasonal variations with the highest total biomass in the dry and short-wet seasons (November, March and April) and the lowest biomass during peak rainy season, July-August, 2012 (Fig. 3). The overall mean $( \pm \mathrm{SD})$ standing biomass of zooplankton for Lake Wonchi was $62.02 \pm 25.76 \mathrm{mg} \mathrm{DM} \mathrm{m}^{-3}$. Cladocerans contributed $53 \%$ to the total zooplankton biomass, whereas copepods and rotifers contributed $39 \%$ and $8 \%$, respectively (Fig. 4, top panel). The highest biomass of cladocerans (89.96 $\mathrm{mg} \mathrm{DM} \mathrm{m}^{-3}$ ) was recorded in March 2012, while the lowest biomass $\left(12.42 \mathrm{mg} \mathrm{DM} \mathrm{m}^{-3}\right)$ was recorded during the last week of July 2012, respectively (Fig. 4, top panel). In contrast, highest biomass (42 mg $\mathrm{DM} \mathrm{m}{ }^{-3}$ ) of copepods was recorded during the dry and short-wet seasons, however its relative importance declined substantially during the rainy-season (Fig. 4, top panel). The contribution of rotifers to the total zooplankton standing biomass during this study (range: $0.25-30.52$ $\mathrm{mg} \mathrm{DM} \mathrm{m}{ }^{-3}$ ) was far less. Apparently, there was a weak, but significant positive correlation between Chl- $a$ and zooplankton biomass ( $\mathrm{r}=0.482, \mathrm{~N}=20, \mathrm{P}=0.037)$ throughout the study period.

Zooplankton displayed some dispersion along the epiand metalimnion. The dominant cladoceran $D$. longispina was almost exclusively aggregated in the narrow band of 1-4 m (Fig. 5). In contrast, C. reticulata was relatively evenly distributed down to $10 \mathrm{~m}$ exhibiting its peak abundance at $3.5 \mathrm{~m}$ of water column, while $B$. longirostris was clustered between 4 and $9 \mathrm{~m}$ of depth (Fig. 5). Thermocyclops ethiopiensis and copepod nauplii were found along the entire epilimnion, however, $50 \%$ of their relative biomass was recorded at around $3 \mathrm{~m}$ (Fig. 5). The dominant rotifers $K$. cochlearis and $A$. sieboldii occupied different depth-habitats during the study period, with $K$. cochlearis dwelling between 1 and $8 \mathrm{~m}$, and $A$. sieboldii staying closer to the upper layers of the water column between 0 and $4 \mathrm{~m}$, respectively. The DVM data did not show significant migration patterns between day and night for all zooplankton taxa during our $24 \mathrm{~h}$ sampling (Fig. 6). Interestingly, the dominant species displayed a bimodal vertical distribution, with a shallow peak at 3-5 $\mathrm{m}$, and a deeper one at the depth of 10-15 m (Fig. 6). nMDS resulted in a 3-dimensional model (minimum stress 0.1 ), which revealed similar community composition except May (group A) and December-January (group B; Fig. 7). Linking the biological data to variables of potential importance showed that temperature, alkalinity, specific conductivity and $\mathrm{NO}_{3}-\mathrm{N}$ had major influence on the pattern (BIOENV-test routine) and revealed that group A (Fig. 7) was separated from the other dates by a slightly elevated temperature of $16.6^{\circ} \mathrm{C}$ and alkalinity of $2.52 \mathrm{meq} \mathrm{L}^{-1}$
(LINKTREE; $\mathrm{P}<0.05$ ), while group $\mathrm{B}$ was pruned from the remaining sampling dates by conductivity $<185 \mu \mathrm{S}$ $\mathrm{cm}^{-1}$ (LINKTREE; $\mathrm{P}<0.10$ ).

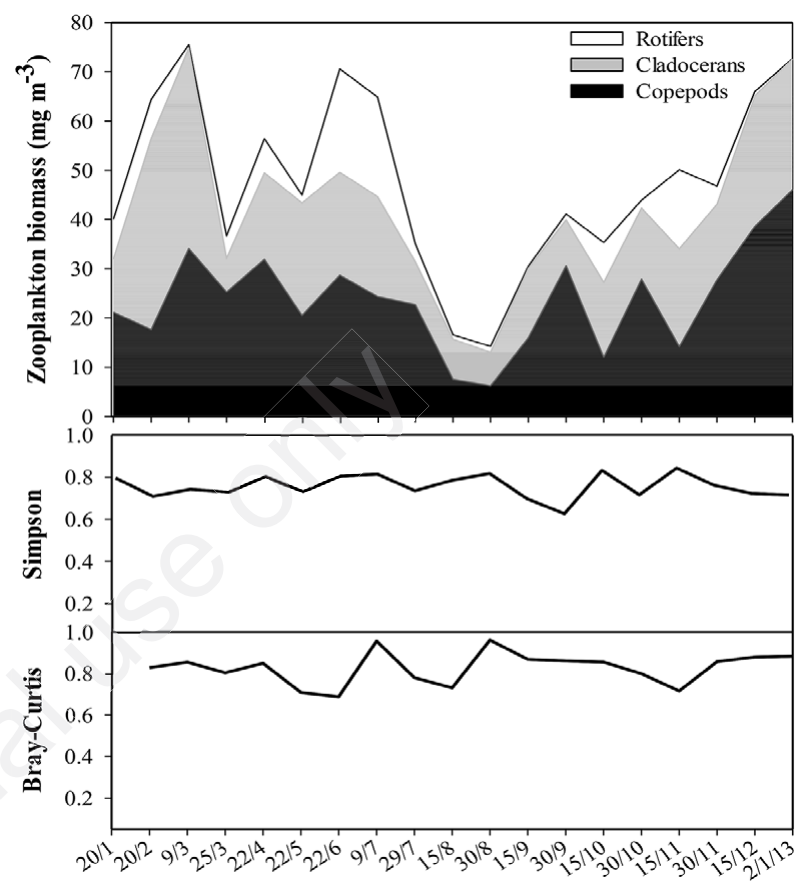

Fig. 4. Zooplankton biomass (groups; top), Simpson's index of diversity (center) and Bray-Curtis similarity (bottom).

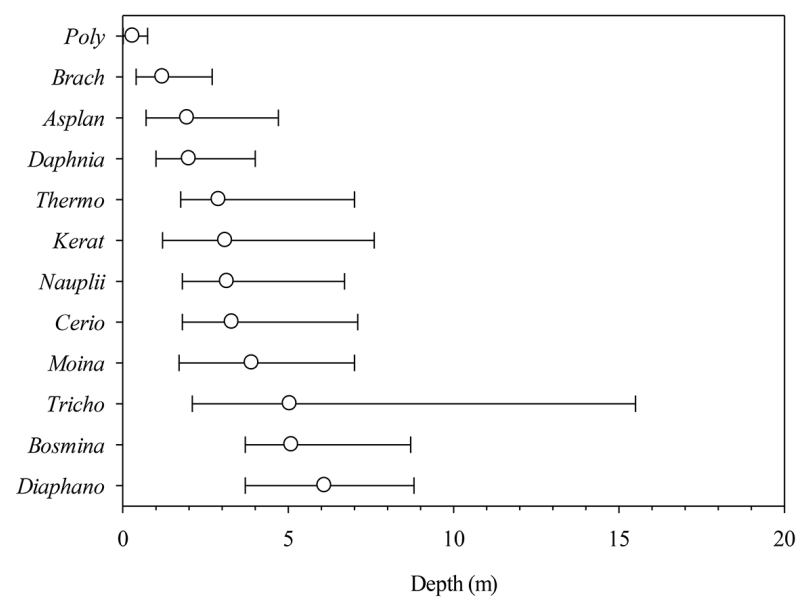

Fig. 5. Vertical distribution of zooplankton taxa summarized over the sampling period. $25-50-75 \%$ of relative abundance at certain depths based on $\mathrm{mg} \mathrm{m}^{-3}(\mathrm{n}, \%)(\mathrm{N}=20)$. Poly-Polyarthra, Brach-Brachionus; Asplan, Asplanchna; Thermo, Thermocyclops; Kerat, Keratella; Cerio, Ceriodaphnia; Tricho, Trichocerca; Diaphano, Diaphanosoma. 


\section{DISCUSSION}

\section{Zooplankton species composition, abundance and biomass}

The pelagic zooplankton standing biomass in Lake Wonchi showed seasonal variation and positive correlation with Chl- $a$ concentrations, which mirrors a bottom-up effect of phytoplankton on zooplankton dynamics in the lake, which has also been documented elsewhere (Brooks and Dodson, 1965; Jeppesen et al., 1997). The decline in zooplankton biomass during the rainy season was likely caused by low abundance of total copepodites during this period (abundance: dry season $118 \times 10^{3} \mathrm{Ind} \mathrm{m}^{-3}$; peak rainy season $63 \times 10^{3} \mathrm{Ind}^{-3}$ ) due to the significant decrease in algal biomass (Chl- $a$ : dry season $7.0 \mu \mathrm{g} \mathrm{L}^{-1}$; peak rainy season $1.3 \mu \mathrm{g} \mathrm{L}^{-1}$, Fig. 3) and the possible competition by D. longispina for limited food sources. The overall mean standing biomass of zooplankton around $62.02 \mathrm{mg} \mathrm{DM} \mathrm{m}^{-}$ ${ }^{3}$ is low compared to the results obtained from other highland and rift valley lakes in Ethiopia (Wondie and Mengistu, 2006; Dagne et al., 2008; Fetahi et al., 2011; Haileselasie et al., 2012). The zooplankton abundance of Lake Wonchi was dominated by Thermocyclops ethiopiensis (50\%) and cladocerans (38\%), which is in agreement with several other authors, who also reported low abundance of rotifers compared to crustacean in other highmountain tropical lakes (Gillooly and Dodson, 2000; Fetahi et al., 2011; Dejenie et al., 2012; Haileselasie et al., 2012). Comparison of zooplankton species composition from Lake Wonchi with the data from other high-mountain lakes in Ethiopia revealed some remarkable trends. For instance, a seasonal study on zooplankton community composition from the high altitude tropical Lake Hayq showed that Thermocyclops ethiopiensis and D. magna were very abundant (Fetahi et al., 2011), which is in accordance with this study. The high abundance of crustaceans is quite exceptional to the scenario observed in most lowland tropical water bodies, where the less competitive and smaller planktonic species, mostly rotifers, predominate (Nilssen, 1984; Fernando et al., 1990; Dumont, 1994; Dagne et al., 2008). The possible explanations for the paucity of rotifers in Lake Wonchi could be either high predation from the abundant Thermocyclops ethiopiensis or the possible interference and exploitative competition from $D$. longispina for limited food sources (mean algal biomass Chl- $a$ : 3.1 $\left.\pm 1.6 \mu \mathrm{g} \mathrm{L}^{-1}\right)$. Such interference and exploitative competition between crustaceans and rotifers and the mechanism by which especially large-bodied cladoceran (e.g., Daphnia) suppress rotifer populations have already been well documented (Brooks and Dodson, 1965; Gilbert, 1988; Fernando et al., 1990; Shurin et al., 2006). In this regard, cladocerans are considered to be the most effective grazers in freshwater lakes and at times ingest over $80 \%$ of the phytoplankton biomass (Jeppesen et al., 1997;
Shurin et al., 2006; Iglesias et al., 2011). Indeed, this was evident in Lake Wonchi, where rotifers (in particular $K$. cochlearis) were almost vanished during the short-wet period when the cladocerans (mainly $D$. longispina) abundance peaked to their mean maxima for the study period (Fig. 4, top panel). However, they recurred and exhibited peaks during the dry periods (April and December), where increasing temporal variation in the phytoplankton abundance was also observed coupled with the lake mixing period (Figs. 2 and 4, top panel). Therefore, the possible exploitative competitions between the obligate grazers significantly dictate their seasonal succession in Lake

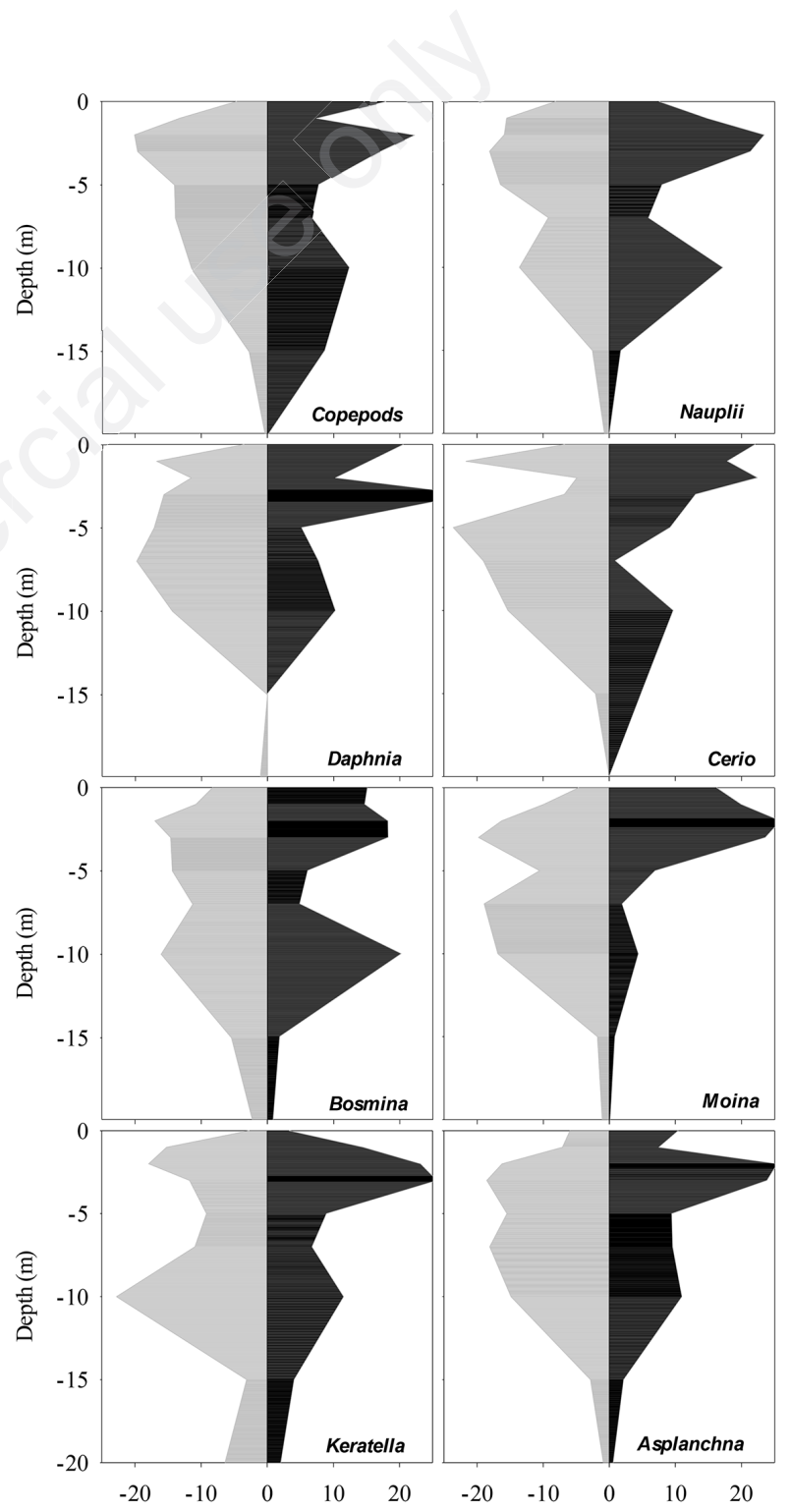

Fig. 6. Day (grey; mean of 6, 10, 14 h) and night (black; mean of $18,22,2 \mathrm{~h}$ ) distribution of taxa during a 24 -h sampling. Data presented as percentage (Ind $\mathrm{m}^{-3}$ ) over depth. 
Wonchi, probably to avoid similar food niches. Nevertheless, nMDS analysis indicated comparable community composition (group C in Fig. 7) except during December, January (group B) and May (group A), which coincided with the dry season. BIOENV-test routine revealed that group A was separated from the other dates by a slightly elevated temperature and alkalinity, while Group B was pruned from the remaining sampling dates by slight change in conductivity.

Contrasting to copepods ( 1 taxon), our investigations revealed relatively high diversity of the limnetic cladocerans (6 taxa, Tab. 2), which is probably attributed to their high dispersal rate as compared with copepods. Cladocerans have a special ability to produce resting eggs parthenogenetically during unfavourable conditions and hence viable resting eggs are transported into remote isolated water bodies by waterbirds as they migrate between lakes (De Meester et al., 2002; Figuerola and Green, 2002; Green et al., 2002). Besides, D. longispina was copious in Lake Wonchi (40\% of total cladoceran abundance), which is in contrast with the general opinion that large-bodied species of cladocerans are sporadic or lacking in tropical water bodies (Dumont, 1994; Gillooly and Dodson, 2000; Meerhoff et al., 2007; Dejenie et al., 2012). The plausible explanations are: i) the lack of strict zooplanktivores in the pelagic zone; Degefu et al. (2014) reported that Cyprinus carpio (a facultative zooplanktivorous species) and Garra sp. (a riverine, strict benthic species) are the only fish species inhabited Lake Wonchi with very low abundance; this further pointed towards a non-existing top-down control of zooplankton by fish, which was also observed elsewhere in a series of mesocosm experiments using Garra sp. as sole zooplanktivorous organism (Dejenie et al., 2012); ii) the high altitude $(2887 \mathrm{~m})$ at which the lake is located and the subsequent low water temperature (annual mean: $15.7 \pm 0.6^{\circ} \mathrm{C}$ ) for a tropical lake. Similar evidence was documented from the highland lakes and reservoirs in Ethiopia, where high abundance and diversity of large-bodied cladocerans including temperate species such as D. hyalina and C. dubia were identified (Dejen et al., 2004; Dejenie et al., 2012). At a first glance, the occurrence of large-bodied cladocerans is contradicting the findings of decreasing size with latitude, because Gillooly and Dodson (2000) demonstrated a decrease in body size of limnetic cladocerans across latitude, suggesting that water temperature is pivotal for the observed pattern, since the upper thermal tolerance of large-bodied cladocerans (mainly Daphnia) is surpassed in tropical lakes. Besides, size-selective predation of fish is substantial in tropical lakes due to the indirect effect of high water temperature on fish recruitment and the subsequent predation impact of high biomass of 0+ fishes on daphnids (Flik, 2000). Interestingly, highmountain lakes in tropical regions appear to be excep- tional to the general view of latitudinal patterns of cladoceran body size recounted. For instance, Fernando et al., (1987) and Green (1995) reported large-bodied cladocerans from both temperate and high-mountain tropical lakes. In the studies mentioned above, the authors found more similarities in the thermal regimes of tropical highmountain lakes with those lakes at higher latitude, than lakes at lower elevations at the same latitude. Therefore, we assume that low water temperature is the key factor for the observed dominance of daphnids.

\section{Vertical distribution of zooplankton}

It is generally accepted that the vertical distribution pattern of zooplankton is induced by factors such as water temperature, UV-radiation, food availability, oxygen saturation, competition and predation (Loose and Dawidowicz, 1994; Winder et al., 2004). Zooplankton of Lake Wonchi displayed some degree of segregation along the epi- and metalimnion during the study period, which was mainly evident among the herbivorous filter-feeders (Fig. 5). D. longispina almost exclusively occupied the upper section of the epilimnion, where food is more abundant (annual mean Chl- $a \sim 4 \mu \mathrm{g} \mathrm{L}^{-1}$ in the top $10 \mathrm{~m}$, data not shown) and did not descend below $4 \mathrm{~m}$ in higher number. $D$. excisum and $C$. reticulata displayed relatively broader vertical distribution and occupied the lower boundaries of the epilimnion, whereas $B$. longirostris was restricted to the upper

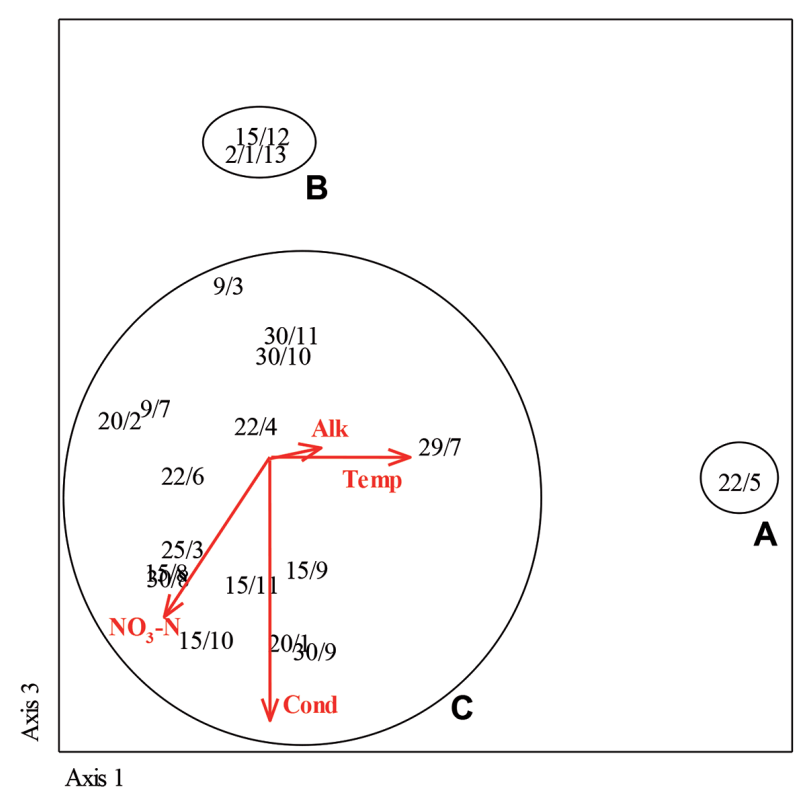

Fig. 7. nMDS-plot of zooplankton taxa with post-projected variables and grouping according to LINKTREE routine. Alk, total alkalinity; Temp, temperature; Cond, conductivity. 
section metalimnion (Fig. 5). As the water column did not display apparent vertical gradients in the key physicochemical variables (e.g., DO concentrations $0-15 \mathrm{~m}$ was fairly above $2 \mathrm{mg} \mathrm{O}_{2} \mathrm{~L}^{-1}$, a threshold concentration for cladocerans), competitive exclusion for limited resources probably accounted for the vertical distribution of the herbivorous filter-feeders. It was evident that inferior competitors such as $B$. longirostris circumvented the upper section of the epilimnion (Fig. 5). Such intense exploitative competition has already been reported earlier: DeMott and Kerfoot (1982) indicated that Bosmina is strongly suppressed by competition from Daphnia. Apparently, copepods almost co-existed with $D$. longispina along the entire epilimnion irrespective of their wide overlap in food spectrum. Nevertheless, copepods can ingest large food particles and select between food items to avoid competitive exclusion from cladocerans, as has been well-documented earlier (Gliwicz, 1980; De Moott, 1988).

In Lake Wonchi, the dominant rotifer species displayed a clear-cut spatial segregation during the entire study period. Interestingly, the invertebrate predator $A$. sieboldii occupied the uppermost section of epilimnion, whereas the herbivorous $K$. cochlearis was restricted to the lower boundaries of epilimnion (Fig. 5). The extended distribution of $K$. cochlearis to the metalimnion is probably a behavioral response to evade both competition (exploitative and interference) from $D$. longispina and predation from A. sieboldii at the surface. Apparently, $K$. cochlearis survived in the metalimnion probably due to its evolutionary adaptation to low food concentrations, which is also a characteristic feature for oligotrophic conditions (Ruttner-Kolisko, 1974, Walz, 1997). The DVM study during our $24 \mathrm{~h}$ sampling displayed bimodal distribution of zooplankton abundance in Lake Wonchi (Fig. 6). The first peak (at 3-5 m) was associated with algal biomass maxima (annual mean Chl- $a$ in upper epilimnion, data not shown), while a deeper one at the depth of 10-15 $\mathrm{m}$ was probably attributed to increased bacteria numbers. This remains however speculative until further research will be conducted to quantify bacteria abundance and elucidate the trophic role and interaction of zooplankton grazing on bacteria in the lake.

\section{CONCLUSIONS}

Lake Wonchi can be categorized under oligotrophic status with mean trophic status index of 36 . The zooplankton community composition of Lake Wonchi harbours both temperate and tropical species possibly due to the high altitude at which the lake is located and the subsequent low water temperature for a tropical lake. The seasonal dynamics of zooplankton biomass was mainly correlated with Chl- $a$ concentration, which reflects a bottom-up effect of algal biomass on zooplankton dynamics. It can be concluded that fish predation pressure is not the key factor structuring the vertical distribution of zooplankton in Lake Wonchi.

\section{ACKNOWLEDGMENTS}

We appreciate the financial support of the Austrian Partnership Program in Higher Education and Research for Development (APPEAR). We also thank EIAR-National Fisheries and Aquaculture Research Center (NFLARC) for logistic support during this study. Special thanks to K. Teshome for his unwavering support during field sampling and laboratory analysis. Many thanks to S. Abere and B. Jemal, who assisted during sample collection and laboratory analysis. We also thank A. Herzig and A. Dagne for identification help and T. Dadi for handling the field equipment.

\section{REFERENCES}

APHA, 1998. Standard Methods for the Examination of Water and Wastewater, 20th ed. American Public Health Association, Washington DC, USA.

Boon PL, Shiel RJ, 1990. Grazing on bacteria by zooplankton in Australian billabongs. Aus. J. Mar. Freshwt. Res. 41:247-257.

Brooks JL, Dodson SI, 1965. Predation, body size, and composition of plankton. Science 150:28-35.

Bryce DL, 1931. Report on the Rotifera: Mr. Omer-Cooper's investigation of the Abyssinian freshwater (Dr. Hugh Scott Expedition). Pages 865-878 in Proceeding of the Zoological Society of London.

Cannicci G, Almagia F, 1947. [Notizie sulla "Facies" planctonica di alcuni laghi della Fossa Galla].[Article in Italian]. Boll. Pesca Piscicolt. Idrobiol. 2:54-77.

Carlson RE, 1977. A trophic state index for lakes. Limnol. Oceanogr. 22 361-369.

Carpenter RS, Kitchell FJ, 1993. Cascading trophic interactions, p. 385. In: R.S. Carpenter and F.J. Kitchell (eds.), The trophic cascade in lakes. Cambridge University Press.

Clarke KR, Gorley RN, 2006. Primer V6: user manual/tutorial. PRIMER-E, Plymouth.

Clarke KR, Somerfield PJ, Gorley RN, 2008. Testing of null hypotheses in exploratory community analyses: similarity profiles and biota-environment linkage. Exp. Mar. Biol. Ecol. 336:56-69.

Dagne A, Herzig A, Jersabek C, Tadesse Z, 2008. Abundance, species composition and spatial distribution of planktonic rotifers and crustaceans in Lake Ziway (Rift Valley, Ethiopia). Int. Rev. Hydrobiol. 93:210-226.

Defaye D, 1988. [Contribution à la connaissance des Crustacés Copépodes d'Ethiopie].[Article in French]. Hydrobiologia 164:103-147.

Degefu F, Herzig A, Jirsa F, Schagerl M, 2014. First limnological records of highly threatened tropical high-mountain crater lakes in Ethiopia. Trop. Conserv. Sci. 7:365-381.

Dejen E, Vijverberg J, Nagelkerke LAJ, Sibbing FA, 2004. Temporal and spatial distribution of microcrustacean zooplankton in relation to turbidity and other environmental factors in a large tropical lake (L. Tana, Ethiopia). Hydrobiologia 513:39-49.

Dejenie T, Declerck AJS, Asmelash T, Risch S, Mergeay J, Bie 
TD, Meester DL, 2012. Cladoceran community composition in tropical semi-arid highland reservoirs in Tigray (Northern Ethiopia): a meta community perspective applied to young reservoirs. Limnologica 42:137-143.

De Meester L, Gomez A, Okamura B, Schwenk K, 2002. The monopolisation hypothesis and the dispersal-gene flow paradox in aquatic organisms. Acta Oecologica 23:121-135.

DeMott WR, 1988. Discrimination between algae and artificial particles by freshwater and marine copepods. Limnol. Oceanogr. 33:397-408.

DeMott WR, Kerfoot WC, 1982. Competition among cladocerans: nature of the interaction between Bosmina and Daphnia. Ecology 63:1949-1966.

Dumont HJ, 1994. On the diversity of the Cladocera in the tropics. Hydrobiologia 272:27-38.

Dumont HJ, Van De Velde I, Dumont S, 1975. The dry weight estimate of biomass in a selection of Cladocera, Copepoda and Rotifera from the plankton, periphyton and benthos of continental waters. Oecologia (Berl.) 19:75-97.

Fernando CH, 2002. A guide to tropical freshwater zooplankton. Identification, ecology and impact on fisheries. Backhuys: $291 \mathrm{pp}$.

Fernando CH, Mengistu S, Bely S, 1990. The chydroid crustacean Alona diaphana (KING), limnetic in Lakes Awasa and Ziway, Ethiopia, with a discussion of littoral and limnetic zooplankton. Int. Revue Ges. Hydrobiol. 75:15-25.

Fernando CH, Paggi J, Rajapaka R, 1987. Daphnia in tropical lowlands. In: R.H. Peters and R. De Bernardi (eds.) Daphnia. Mem. Ist. Ital. Idrobiol. 45:107-141.

Fetahi T, Mengistu S, Schagerl M, 2011. Zooplankton community structure and ecology of the tropical-highland Lake Hayq, Ethiopia. Limnologica 41:389-397.

Figuerola J, Green AJ, 2002. Dispersal of aquatic organisms by waterbirds: a review of past research and priorities for future studies. Freshwater Biol. 47:483-494.

Flik BJG, 2000. Size selective feeding of 0+ perch during a period of diel vertical migration of Daphnia. Verh. Int. Verein. Limnol. 27:3019.

Gilbert JJ, 1988. Suppression of rotifer population by Daphnia: a review of the evidence, the mechanisms, and the effects on zooplankton community structure. Limnol. Oceanogr. 33:1286-1303.

Gillooly JF, Dodson SI, 2000. Latitudinal patterns in the size distribution and seasonal dynamics of new world, freshwater Cladocerans. Limnol. Oceanogr. 45:22-30.

Gliwicz ZM, 1980. Filtering rates, food size selection, and feeding rates in cladocerans - another aspect of interspecific competition in filter-feeding zooplankton. In: W.C. Kerfoot (ed.), Evolution and ecology of zooplankton communities. University Press of New England.

Green J, 1986. Zooplankton associations in some Ethiopian crater lakes. Freshwater Biol. 16:495-499.

Green J, 1995. Altitudinal distribution of tropical planktonic Cladocera. Hydrobiologia 3307: 75-84.

Green J, Figuerola J, Sanchez MI, 2002. Implications of waterbirds ecology for the dispersal of aquatic organisms. Acta Oecol. 23:177-189.

Green J, Mengstou S, 1991. Species diversity and community structure of Rotifera in a salinity series of Ethiopian inland waters. Hydrobiologia 209:95-106.
Haileselasie TH, Teferi M, Dejenie T, Welegerima K, Abay T, Hiluf SA, Girmay K, 2012. Abundance, species composition and special distribution of zooplankton in Lake Hashengie of Tigray, Northern Ethiopia. Curr. Res. J. Biol. Sci. 4:389-393.

Iglesias C, Mazzeo N, Meerhoff M, Lacerot G, Clemente JM, Scasso F, Kruk C, Goyenola G, Garcia-Alonso J, Amsinck SL, Paggi JC, Paggi SJ, Jeppesen E, 2011. High predation is of key importance for dominance of small-bodied zooplankton in warm shallow lakes: evidence from lakes, fish exclosures and surface sediments. Hydrobiologia 667:133- 147.

Jeppesen E, Jensen TP, Søndergaard M, Lauridsen T, Pedersen LJ, Jensen L, 1997. Top-down control in freshwater lakes: the role of nutrient state, submerged macrophytes and water depth. Hydrobiologia 343:151-164.

Korinek V, 1999. A guide to limnetic species of Cladocera of African inland waters (Crustacea, Branchiopoda). Volta Basin Research Project: 57 pp.

Korovchinsky NM, 1992. Sididae and Holopedidae: guides to the identification of microinvertebrates of the continental waters of the world. SPB Academic Publ.: 82 pp.

Koste W, 1978. [Rotatoria: die Radertiere Mitteleuropas begrundet von Max Voigt].[Book in German]. Gebruder Borntraeger.

Lampert W, Sommer U, 1997. Limnoecology: the ecology of lakes and streams. Oxford University Press: $382 \mathrm{pp}$.

Lemma B, 2009. Observations on the relations of some physicochemical features and DVM of Paradiaptomus africanus in lakes Bishoftu-Guda and Hora-Arsedi, Bishoftu, Ethiopia. Limnologica 39:230-243.

Loose CJ, Dawidowicz P, 1994. Trade-offs in diel vertical migration by zooplankton: the costs of predator avoidance. Ecology 75:2255-2263.

McCune B, Grace JB, 2002. Analysis of ecological communities. MJM Software Design, Gleneden Beach, OR, USA.

Meerhoff M, Iglesias C, Teixeria de Mello F, Clemente JM, Jensen E, Lauridsen TL, Jeppesen E, 2007. Effect of habitat complexity on community structure and predator avoidance behavior of littoral zooplankton in temperate versus subtropical shallow lakes. Freshwater Biol. 52:1009-1021.

Mengistu S, Fernando CH, 1991. Biomass and production of major dominant crustacean zooplankton in a tropical rift valley lake, Awasa, Ethiopia. J. Plankton Res. 13:831-852.

Mengistu S, Green J, Fernando CH, 1991. Species composition, distribution and seasonal dynamics of Rotifera in a Rift Valley lake in Ethiopia (Lake Awasa). Hydrobiologia 209 203-214.

Nilssen JP, 1984. Tropical lakes-functional ecology and future developments: the need for a process-oriented approach. Hydrobiologia 113:231-242.

Ruttner-Kolisko A, 1974. Plankton rotifers, biology and taxonomy. Schweizerbartische Verlagsbuchhandlung: 146 pp.

Ruttner-Kolisko A, 1977. Suggestions for biomass calculation of plankton rotifers. Arch. Hydrobiol. Beih. 8:71-76.

Shurin JB, Gruner DS, Hillebrand H, 2006. All wet or dried up? Real differences between aquatic and terrestrial food webs. P. Roy. Soc. Lond. B Bio. 273:1-9.

Talling JF, Driver D, 1963. Some problems in the estimation of chlorophyll a in phytoplankton. Page 142-146 in Proc. Conference on Primary Productivity Measurements, Marine and Freshwater, US Atomic Energy Commission.

Tudorancea C, Fernando CH, Paggi JC, 1988. Food and Feed- 
ing Ecology of Oreochromis niloticus (LINNAEUS, 1758) juveniles in Lake Awassa, Ethiopia. Arch. Hydrobiol. 79: 267-289.

Vijverberg J, Dejen E, Getahun A, Leopold A, Nagelkerke J, 2014. Zooplankton, fish communities and the role of planktivory in nine Ethiopian lakes. Hydrobiologia 722:45-60.

Walz N, 1997. Rotifer life-history strategies and evolution in freshwater plankton communities, p. 119-149. In: B. Streit, T. Städler and C.M. Lively (eds.), Evolutionary ecology of freshwater animals. Springer.
Wetzel RG, Likens GE, 2000. Limnological analyses. 3. Springer: 429 pp.

Winder M, Spaak P, Mooij WM, 2004. Trade-offs in Daphnia habitat selection. Ecology 85:2027-2036.

Wodajo K, Belay A, 1984. Species composition and seasonal abundance of zooplankton in two Ethiopian Rift valley lakes, Lakes Abiata and Langano. Hydrobiologia 113:129-136.

Wondie A, Mengistu S, 2006. Duration of development, biomass and rate of production of the dominant copepods (Calanoida and Cyclopoida) in Lake Tana, Ethiopia. Ethiop. J. Sci. 29:107-122. 